\title{
ASSESSING WATER QUALITY OF BOYALI DAM LAKE (SINOP, TURKEY) BY USING ECOLOGICAL AND STATISTICAL INDICATORS
}

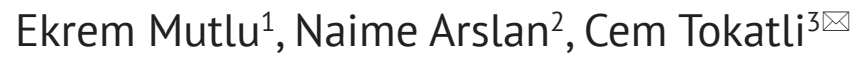 \\ ${ }^{1}$ Aquaculture Department, Kastamonu University, Turkey \\ ${ }^{2}$ Biology Department, Eskişehir Osmangazi University, , Turkey \\ ${ }^{3}$ Laboratory Technology Program, Trakya University, İpsala/Edirne, Turkey
}

\begin{abstract}
Aim of the study

In the present study, the spatial-temporal variations of water quality in Boyalı Pond were analyzed. Water Quality Index (WQI) based on the World Health Organization's standards specified for drinking water and Water Quality Control Regulations in Turkey (WQCR), as well as certain multi-statistical methods, were used in analyzing the water quality.
\end{abstract}

\begin{abstract}
Material and methods
Water samples were collected from 5 stations selected in the lake on monthly basis in 2019 and 30 water quality parameters were measured in total. Water Quality Index (WQI), Factor Analysis (FA), and Cluster Analysis (CA) were used in order to determine the differences between the spatial and temporal quality levels and to classify the investigated locations.
\end{abstract}

\section{Results and conclusions}

According to data observed, Boyalı Dam Lake was found to have Class I and Class II water quality. In general, the WQI results obtained suggested that, although the water quality was found to significantly decrease in summer months, the reservoir was found to have an "A Grade - Excellent" water quality $(<50)$ in all the months and stations analyzed here. WQI values recorded in the dam lake ranged between 16.4 and 27.8 and the detected limnologic parameters did not exceed the standards specified for drinking water in any of the investigated months and stations ( $<50$ for WQI). As a result of FA, 3 factors explained $88.9 \%$ of total variances and as a result of CA, 2 statistical clusters were formed.

Keywords: Boyalı Dam Lake, Water Quality Index, Factor Analysis, Cluster Analysis

\section{INTRODUCTION}

Pollution of water ecosystems is an important environmental problem and it is known that one of the significant points for an effective water source management is to frequently monitor the quality of aquatic environments (Varol et al., 2012; Tokatl1 et al., 2014; 2016; Köse et al., 2015; 2016).
Water quality assessment indices are effective tools and they may be useful in evaluating the quality of water ecosystems. Water Quality Index (WQI) is one of the best and most commonly used freshwater quality indices and it is calculated from the perspective of suitability of water in terms of human consumption (Tyagi et al., 2013; Akter et al., 2016; Mukatea et al., 2019; Ustaoğlu and Tepe, 2019; Varol, 2019; Ustaoğlu

凶e-mail:cemtokatli@trakya.edu.tr 
and Aydın, 2020; Tokatlı et al., 2021; Tokatlı and Varol, 2021).

Multivariate statistical methods that are widely used all over the world in many different aquatic habitats are another useful and powerful tools to evaluate the water quality and source identification of pollutants. Cluster Analysis (CA) that is being used to classify the objects in terms of their similar characteristics and Factor Analysis (FA) that is being used to determine the effective factors on the water environment and facilitates the interpretation of large data sets are two of the most widely used and fairly powerful statistical methods to evaluate the aquatic conditions (Köse et al. 2014; Çiçek et al., 2019; Ustaoğlu et al., 2020).

Boyalı Dam Lake, which is a significant artificial lentic ecosystem located in Sinop Province of Turkey, has a great importance for the local people. The purpose of construction of this reservoir was to irrigate the agricultural land around and to meet the domestic water needs of Emiroğlu and Benişli Villages. It was also stated that, if necessary, the dam lake would meet the domestic and drinking water needs of Boyabat District, where the population is up to 30,000 individuals. The aim of the present research was to evaluate the spatial-temporal variations of water quality in Boyalı Dam Lake by using WQI and several widely-used multistatistical techniques.

\section{MATERIALAND METHOD}

\section{Sample Collection}

Water samples were taken from 5 stations located on the Boyalı Dam Lake on monthly basis in 2019. The coordinates of locations are given in Table 1 and the map of the study area with selected stations on the reservoir is shown in Figure 1.

\section{Physical-Chemical Analysis}

Dissolved oxygen (DO), salinity, $\mathrm{pH}$, temperature and electrical conductivity (EC) parameters were measured using a pre-calibrated terrain type portable and digital multi-parameter device (Hach Lange, HQ40D). COD, chloride, sulfate, sulfite, phosphate, sodium, potassium, calcium, magnesium, nitrate, ammonium nitrogen, and nitrite parameters were measured using a spectrophotometer device (WTW 7600 UV-VIS). BOD parameter was measured using a BOD measuring set (WTW OXITOP 12). Suspended solids were measured by filtering using a filter paper $(0.45 \mu \mathrm{m})$ (Whatman), whereas the total alkalinity and hardness parameters were measured by using the titrimetric method.

\section{Element Analysis}

In determining the macro and micro elements in water samples, $\mathrm{pH}$ values (one liter) were set to 2 by means of adding $\mathrm{HNO}_{3}$ into each sample. Afterwards, the water samples were filtered by means of a $0.45-\mu \mathrm{m}$ cellulose nitrate filter. Subsequently, their volumes were completed to $50 \mathrm{ml}$ with ultrapure distilled water. Macro and micro element concentrations were determined by using an ICP-OES device (Spectro, SpectroBlue) in Kastamonu University (EPA, 2001).

\section{Statistical Analysis}

Cluster Analysis (in terms of Bray Curtis) was applied to the obtained data in order to define the spatial differences of contamination by using the "PAST" package statistical program. Factor Analysis (FA) was used in order to define the effective variation factors on the system by using the "SPSS 23 " package statistical program.

Table 1. Coordinate information of stations

\begin{tabular}{ccc}
\hline Stations & North & East \\
\hline $\mathbf{1}^{\text {st }}$ Station & $41^{\circ} 22^{\prime} 34.60^{\prime \prime} \mathrm{N}$ & $34^{\circ} 39^{\prime} 19.94^{\prime} \mathrm{E}$ \\
\hline $\mathbf{2}^{\text {nd }}$ Station & $41^{\circ} 22^{\prime} 27.70^{\prime \prime} \mathrm{N}$ & $34^{\circ} 39^{\prime} 46.50^{\prime} \mathrm{E}$ \\
\hline $\mathbf{3}^{\text {rd }}$ Station & $41^{\circ} 22^{\prime} 38.80^{\prime \prime} \mathrm{N}$ & $34^{\circ} 39^{\prime} 47.68^{\prime} \mathrm{E}$ \\
\hline $\mathbf{4}^{\text {th }}$ Station & $41^{\circ} 22^{\prime} 45.43^{\prime \prime} \mathrm{N}$ & $34^{\circ} 39^{\prime} 14.96^{\prime} \mathrm{E}$ \\
\hline $\mathbf{5}^{\text {th }}$ Station & $41^{\circ} 22^{\prime} 43.24^{\prime} \mathrm{N}$ & $34^{\circ} 39^{\prime} 5.05^{\prime \prime} \mathrm{E}$ \\
\hline
\end{tabular}

\section{Water Quality Index (WOI)}

WQI is an effective and widely used technique to assess the water quality (Wang et al., 2017; Tokatl1, 2019; Ustaoğlu et al., 2020; Tokatlı and Ustaoğlu, 2020; Tokatl1, 2021). The following formula was used in calculating WQI (Meng et al., 2016; Xiao et al., 2019); 
Mutlu, E., Arslan, N., Tokatli, C. (2021). Assessing Water Quality of Boyalı Dam Lake (Sinop, Turkey) by Using Ecological and Statistical Indicators. Acta Sci. Pol., Formatio Circumiectus, 20 (1), 77-85. DOI:

$$
\begin{gathered}
W Q I=\sum\left[W_{i} \times\left(\frac{C_{i}}{s_{i}}\right) \times 100\right] \\
W_{i}=\frac{W_{i}}{\Sigma W_{i}}
\end{gathered}
$$

where, $W_{i}$ is relative weight, $\mathrm{C}_{\mathrm{i}}$ is the measured parameter in water and $\mathrm{S}_{\mathrm{i}}$ values are the standard values (TS266, 2005; EC, 2007; WHO, 2011). In the present research, $\mathrm{pH}, \mathrm{EC}, \mathrm{Cl}, \mathrm{SO}_{4}, \mathrm{Na}, \mathrm{NO}_{2}, \mathrm{NO}_{3}, \mathrm{~Pb}, \mathrm{Cu}, \mathrm{Cd}$, $\mathrm{Hg}$, Ni and $\mathrm{Zn}$ parameters were used for calculating (2) WQI and the scale of WQI is given in Table 2 (Xiao et al., 2019).

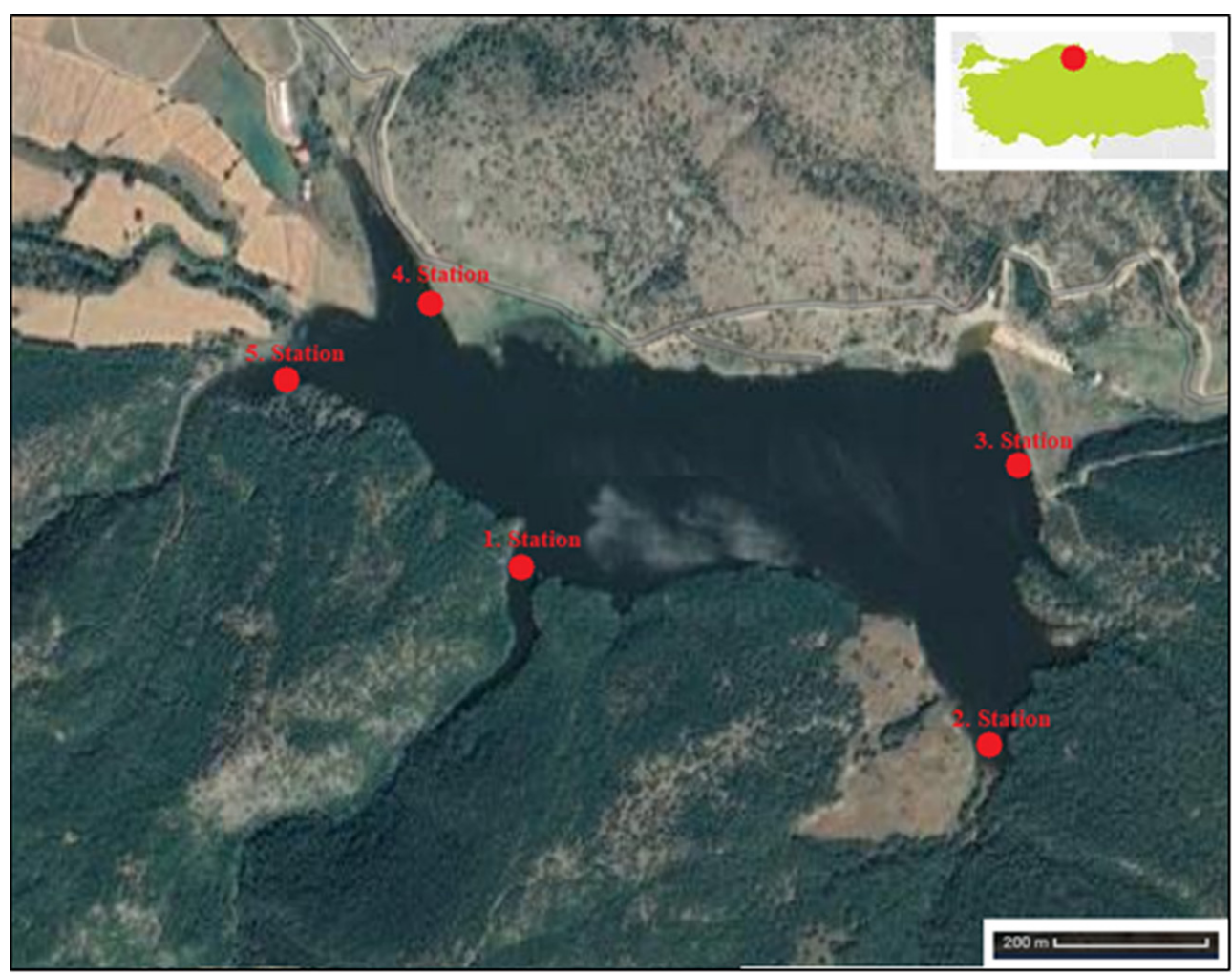

Fig. 1. Boyalı Dam Lake and selected stations

Table 2. Water quality ratings for applied indices

\begin{tabular}{cllc}
\hline Value & \multicolumn{1}{c}{ Rating of Water Quality } & Usage Possibilities & Grading \\
\hline$<50$ & Excellent water quality & Drinking, irrigation, industrial & $\mathrm{A}$ \\
\hline $50-100$ & Good water quality & Drinking, irrigation, industrial & $\mathrm{B}$ \\
\hline $100-200$ & Poor water quality & Irrigation, industrial & $\mathrm{C}$ \\
\hline $200-300$ & Very Poor water quality & Irrigation & $\mathrm{D}$ \\
\hline$>300$ & Unsuitable for drinking purpose & Treatment is required before use & $\mathrm{E}$ \\
\hline
\end{tabular}




\section{RESULTS AND DISCUSSION}

\section{Water Quality}

Annual mean results of limnological parameters detected in Boyalı Dam Lake with Standard Deviation values are presented in Table 3. According to the Water Quality Control Regulations in Turkey (WQCR) (2004; 2015), the water of Boyalı Dam Lake has Class I and Class II quality in terms of all the investigated parameters, except for phosphate. It has Class III quality in terms of this parameter (Uslu and Türkman, 1987). It was also determined that none of the sampling locations exceed the standards specified for drinking water in terms of the parameters examined here (TS266, 2005; EC, 2007; WHO, 2011).

Phosphates may enter the water ecosystems by means of phosphor-rich bedrock, human and animal waste, laundry, cleaning, industrial effluents, and especially fertilizer usage. This phosphate contamination becomes a significant risk factor especially for lentic habitats because of the over-fertilization which fertilizes the algae and causes eutrophication. Agricultural applications are among the most significant phosphate sources for surface waters especially in rural areas (Wetzel, 2001; Manahan, 2011). Boyalı Dam Lake is surrounded by agricultural lands and it is thought that the agricultural activities and the use of fertilizers are the most important reasons for the moderately high phosphate concentrations detected in the waters almost in every seasons.

\section{Cluster Analysis (CA)}

Cluster analysis was used in order to reveal the similarity groups among the sampling locations on Boyal1 Dam Lake. The diagram of CA, which was calculated by using the WQI scores of locations, is given in Figure 2 and the calculated similarity coefficient of locations is given in Table 4. As a result of CA, 2 statistically significant clusters were obtained. Cluster 1 (C1) corresponds to the 1st Station, 2nd Station, and 3rd Station, whereas Cluster 2 (C2) corresponds to the 4th Station and 5th Station.

\section{Factor Analysis (FA)}

FA was used in order to define the effective variation factors on water quality of Boyalı Dam Lake by using related variables. Twenty-eight variables were used in order to determine the varifactors (except $\mathrm{Fe}$ and $\mathrm{Cd}$, which were found as unrelated) $(\mathrm{n}=60$ for all parameters). Kaiser-Meyer-Olkin test result was found to be 0.747 showing that the sample adequacy was at a sufficient level ( $>0.5$ ) (Liu et al., 2003). As a result of FA, 3 factors explained $87.9 \%$ of the total variance (see: Fig. 3). The component plot is given in Figure 3 and the parameter loadings for 3 detected components are given in Figure 4.

F1 (the first factor) explained $41 \%$ of total variance. F1 was related to the variables of ammonium $\left(\mathrm{NH}_{4}\right)$, electrical conductivity (EC), suspended solids (SS), biological oxygen demand (BOD), $\mathrm{pH}$, dissolved oxygen (DO), temperature (Temp), nitrate $\left(\mathrm{NO}_{3}\right)$, salinity (Sal), total hardness (TH), total alkalinity (TA), mercury $(\mathrm{Hg})$, calcium $(\mathrm{Ca})$, and magnesium $(\mathrm{Mg})$ (see: Fig. 3, 4 and 5).

F2 (second factor) explained $27 \%$ of total variance. F2 was related to the variables of sulfur (S), sulfate $\left(\mathrm{SO}_{4}\right)$, sodium $(\mathrm{Na})$, nitrite $\left(\mathrm{NO}_{2}\right)$, potassium $(\mathrm{K})$, lead $(\mathrm{Pb})$, copper $(\mathrm{Cu})$, total hardness $(\mathrm{TH})$ and total alkalinity (TA) (see: Fig. 3, 4 and 5).

F3 (third factor) explained 19\% of total variance. F3 was related to the variables of copper $(\mathrm{Cu})$, zinc $(\mathrm{Zn})$, nickel $(\mathrm{Ni})$, magnesium $(\mathrm{Mg})$, chlorine $(\mathrm{Cl})$, chemical oxygen demand (COD), phosphate $\left(\mathrm{PO}_{4}\right)$, and calcium (Ca) (see: Fig. 3, 4 and 5).

\section{Water Quality Index (WQI)}

Monomial and multinomial risks of $\mathrm{pH}, \mathrm{EC}, \mathrm{CI}, \mathrm{SO}_{4}$, $\mathrm{Na}, \mathrm{NO}_{2}, \mathrm{NO}_{3}, \mathrm{~Pb}, \mathrm{Cu}, \mathrm{Cd}, \mathrm{Hg}, \mathrm{Ni}$, and $\mathrm{Zn}$ parameters in water of Boyalı Dam Lake were determined for all the investigated stations and seasons by using Water Quality Index (WQI). The limit values of WHO (2011) and the relative weight data used in the calculation of WQI are given in Table 5 and the data obtained are given in Figure 5. According to the results of WQI, the values of overall WQI were within the permissible limits $(<100)$, and all the investigated stations on the Boyalı Dam Lake in all the seasons were found as "A grade - Excellent" water quality characteristic.

In a study carried out in Thrace Region, the groundwater quality of Ergene River Basin was evaluated by using WQI. According to the results of this research, the heavy metals investigated in groundwater of region were recorded within the hu- 
Mutlu, E., Arslan, N., Tokatli, C. (2021). Assessing Water Quality of Boyalı Dam Lake (Sinop, Turkey) by Using Ecological and Statistical Indicators. Acta Sci. Pol., Formatio Circumiectus, 20 (1), 77-85. DOI:

Table 3. Descriptive statistics of physical and chemical data

\begin{tabular}{|c|c|c|c|c|c|}
\hline Parameter & Minimum & Maximum & Mean & SD & Quality Class* \\
\hline Dissolved Oxygen (ppm) & 9.8800 & 14.1800 & 12.485 & 1.5426 & Class I \\
\hline Salinity $\left(\%_{0}\right)$ & 0.0200 & 0.1000 & 0.0398 & 0.0259 & - \\
\hline $\mathrm{pH}$ & 8.2500 & 8.7500 & 8.4890 & 0.1453 & Class I and II \\
\hline Temperature $\left({ }^{0} \mathrm{C}\right)$ & 2.7000 & 21.500 & 12.346 & 5.8570 & Class I and II \\
\hline Electrical Conductivity $(\mathrm{ms} / \mathrm{cm})$ & 168.12 & 323.26 & 245.70 & 53.007 & Class I \\
\hline Suspended Solids (ppm) & 0.7400 & 4.2200 & 1.9668 & 1.1266 & - \\
\hline Chemical Oxygen Demand (ppm) & 0.8400 & 3.2400 & 1.8183 & 0.6857 & Class I \\
\hline Biological Oxygen Demand (ppm) & 0.3600 & 1.6000 & 0.9581 & 0.3987 & Class I \\
\hline Chlorine (ppm) & 3.3200 & 6.6600 & 5.3273 & 1.0241 & Class I \\
\hline Phosphate (ppm) & 0.0520 & 1.1140 & 0.1951 & 0.1977 & Class III \\
\hline Sulfate (ppm) & 31.300 & 76.860 & 51.752 & 13.803 & Class I \\
\hline Sulfur (ppm) & 0.3400 & 2.7200 & 1.2806 & 0.6984 & Class I \\
\hline Sodium (ppm) & 39.620 & 76.400 & 51.452 & 12.660 & Class I \\
\hline Potassium (ppm) & 3.3800 & 16.540 & 6.9096 & 3.5302 & - \\
\hline Total Hardness (ppm) & 180.32 & 245.72 & 213.18 & 20.656 & - \\
\hline Total Alkalinity (ppm) & 188.26 & 250.16 & 220.01 & 19.144 & - \\
\hline Magnesium (ppm) & 17.500 & 41.500 & 29.138 & 7.8037 & - \\
\hline Calcium (ppm) & 17.680 & 66.440 & 44.434 & 15.815 & - \\
\hline Nitrite (ppm) & 0.0001 & 0.0048 & 0.0012 & 0.0013 & Class I \\
\hline Nitrate (ppm) & 0.1000 & 4.0400 & 2.2276 & 1.3672 & Class I \\
\hline Ammonium (ppm) & 0.0000 & 0.0021 & 0.0006 & 0.0006 & Class I \\
\hline Iron (ppb) & 0.0000 & 1.0000 & 0.0724 & 0.2405 & Class I \\
\hline Lead (ppb) & 0.0000 & 2.0000 & 0.7483 & 0.5334 & Class I \\
\hline Copper (ppb) & 0.0000 & 14.000 & 4.4333 & 3.3312 & Class I \\
\hline Cadmium (ppb) & 0.0000 & 0.3000 & 0.2050 & 0.1032 & Class I \\
\hline Mercury (ppb) & 0.0000 & 0.0070 & 0.0016 & 0.0017 & Class I \\
\hline Nickel (ppb) & 0.0000 & 4.0000 & 1.6166 & 1.1060 & Class I \\
\hline Zinc (ppb) & 4.0000 & 19.000 & 9.2333 & 4.0853 & Class I \\
\hline
\end{tabular}

*Class III and Class IV water qualities are given in bold

man consumption limits (Tokatl1, 2019). In another study carried out in the Black See Region, WQI was used to evaluate the surface water qualities. Similarly with the current data, it was reported that Turnasuyu Stream has "A Grade - Excellent" water quality (Ustaoğlu et al., 2020). In another research conducted in the same region, water quality of the Saraydüzü Dam Lake was monitored for a 1-year period by de- termining 28 basic variables and WQI was applied to data in order to assess the water quality. As a result of this investigation, similar to the current research, WQI scores in the lake were found to range between 17.62 and 29.88 ("A Grade - Excellent" water quality) and tested variables did not exceed the standard values recommended for drinking water (Kükrer and Mutlu, 2019). 
Mutlu, E., Arslan, N., Tokatli, C. (2021). Assessing Water Quality of Boyalı Dam Lake (Sinop, Turkey) by Using Ecological and Statistical Indicators. Acta Sci. Pol., Formatio Circumiectus, 20 (1), 77-85. DOI:

Table 4. Similarity coefficients of locations

\begin{tabular}{lccccc}
\hline & $\begin{array}{c}\mathbf{1}^{\text {st }} \\
\text { Station }\end{array}$ & $\begin{array}{c}\mathbf{2}^{\text {nd }} \\
\text { Station }\end{array}$ & $\begin{array}{c}\mathbf{3}^{\text {rd }} \\
\text { Station }\end{array}$ & $\begin{array}{c}\mathbf{4}^{\text {th }} \\
\text { Station }\end{array}$ & $\begin{array}{c}\mathbf{5}^{\text {th }} \\
\text { Station }\end{array}$ \\
\hline 1. Station & 1 & & & & \\
\hline 2. Station & 0.996 & 1 & & & \\
\hline 3. Station & 0.996 & 0.998 & 1 & & \\
\hline 4. Station & 0.995 & 0.995 & 0.997 & 1 & \\
\hline 5. Station & 0.994 & 0.994 & 0.995 & 0.998 & 1 \\
\hline
\end{tabular}

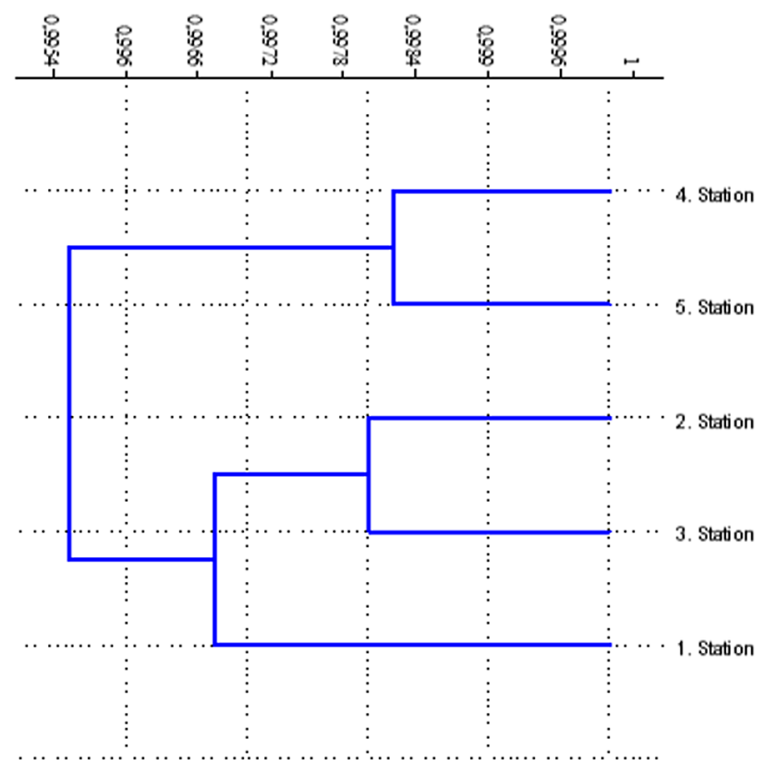

Fig. 2. CA diagram

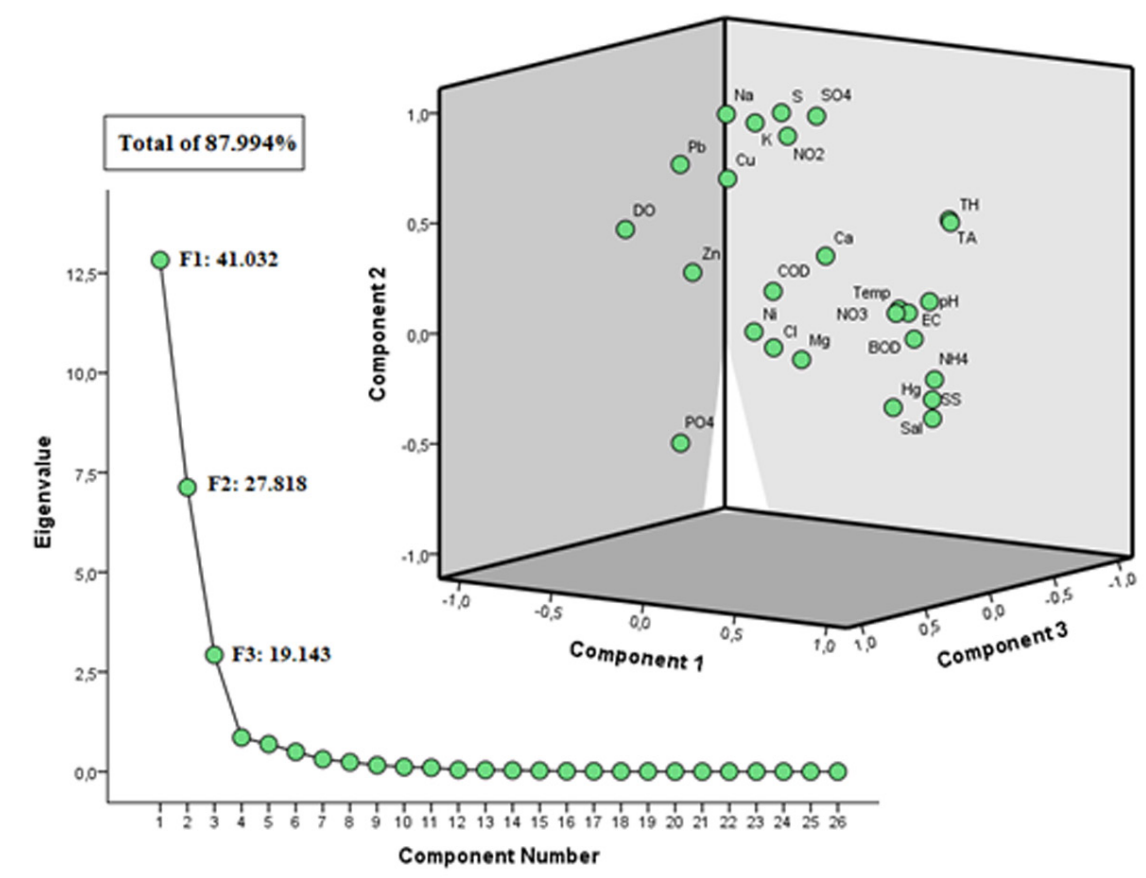

Fig. 3. Scree plot of FA and component plot in rotated space 


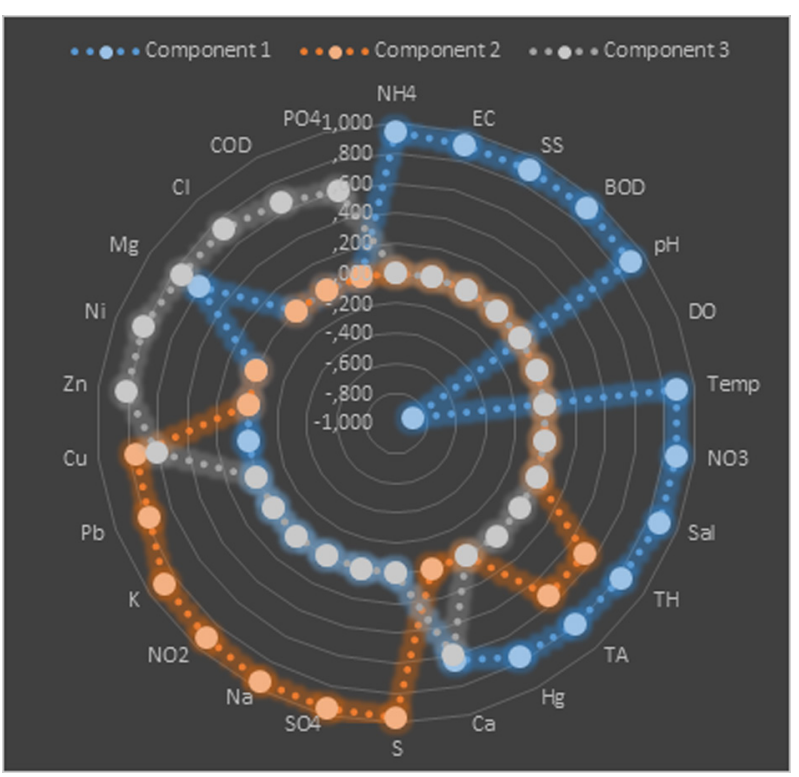

Fig. 4. Rotated component matrix
Table 5. Drinking water limits and relative weight values

\begin{tabular}{|c|c|c|c|}
\hline Parameters & $\begin{array}{c}\text { Standard } \\
\text { Values }(\text { Si) }\end{array}$ & $\begin{array}{c}\text { Assigned } \\
\text { Weight }(\text { AW })\end{array}$ & $\begin{array}{c}\text { Relative } \\
\text { Weight }(\boldsymbol{W i})\end{array}$ \\
\hline $\mathrm{pH}$ & 7.5 & 3 & 0.056 \\
\hline $\mathrm{EC}(\mathrm{ms} / \mathrm{cm})$ & 1500 & 4 & 0.075 \\
\hline $\mathrm{Cl}$ & 5 & 3 & 0.056 \\
\hline $\mathrm{SO}_{4}(\mathrm{ppm})$ & 250 & 3 & 0.056 \\
\hline $\mathrm{Na}$ & 50 & 3 & 0.056 \\
\hline $\mathrm{NO}_{2}(\mathrm{ppm})$ & 3 & 5 & 0.094 \\
\hline $\mathrm{NO}_{3}(\mathrm{ppm})$ & 50 & 5 & 0.094 \\
\hline $\mathrm{Pb}(\mathrm{ppb})$ & 10 & 5 & 0.094 \\
\hline $\mathrm{Cu}(\mathrm{ppb})$ & 2000 & 3 & 0.056 \\
\hline $\mathrm{Cd}(\mathrm{ppb})$ & 3 & 5 & 0.094 \\
\hline $\mathrm{Hg}(\mathrm{ppb})$ & 6 & 5 & 0.094 \\
\hline $\mathrm{Ni}(\mathrm{ppb})$ & 70 & 5 & 0.094 \\
\hline $\mathrm{Zn}(\mathrm{ppb})$ & 3000 & 4 & 0.075 \\
\hline
\end{tabular}

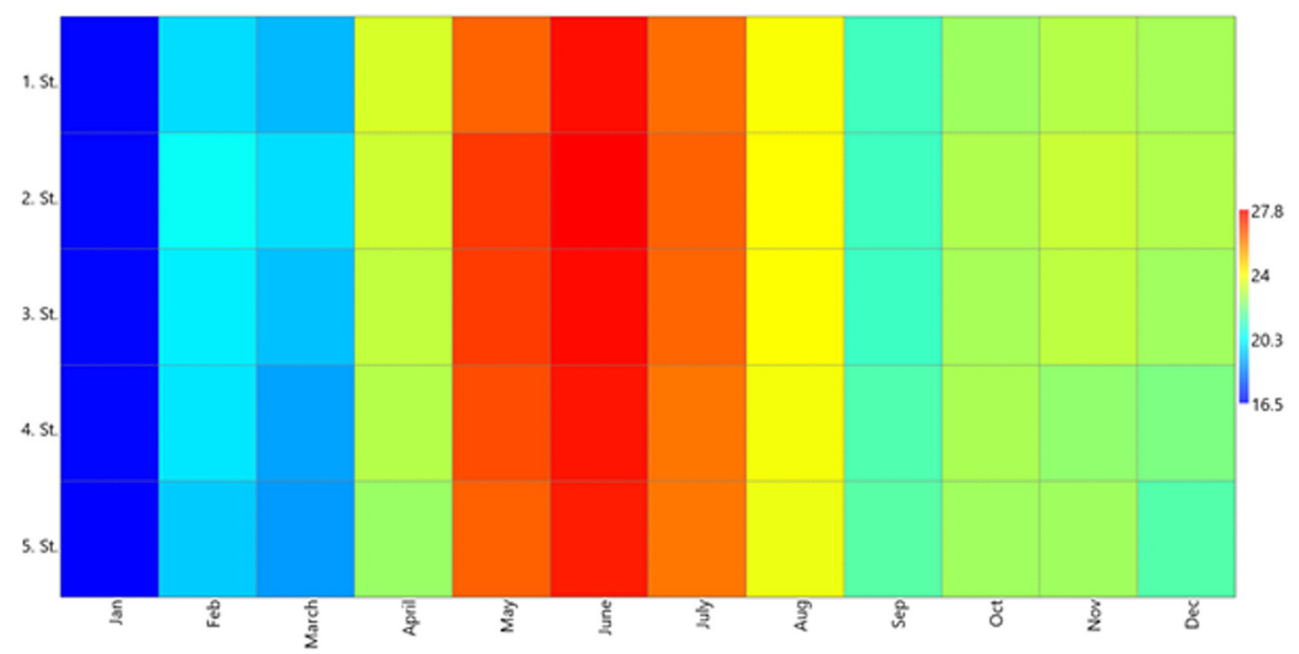

Fig. 5. WQI scores

\section{CONCLUSION}

In the present research, water quality in Boyalı Dam Lake, which is used in order to fulfill the irrigation water needs to the surrounding area and domestic water to nearby settlements area, was assessed by using Water Quality Index (WQI), Factor Analysis (FA), and Clus- ter Analysis (CA). As a result of analyses performed, although the water of reservoir was found to be in Class I and Class II quality classes in general, it was found to be in Class III quality in terms of phosphate parameter. As a result of WQI, although the water quality of the dam lake decreased significantly in summer season, the lake was found to have "A Grade - Excellent" water 
quality $(<50)$ in all the seasons and stations. As a result of FA, 3 factors explained $88.9 \%$ of total variances and 2 statistical clusters were formed as a result of CA.

In conclusion, although the water quality of the Boyalı Dam Lake was found to be at moderately high level, the high phosphate accumulations found in water indicate that the system is being affected by the agricultural activities, and this finding suggests that the reservoir should be constantly monitored in order to protect this important artificial lentic habitat.

\section{REFERENCES}

Akter, T., Jhohura, F. T., Akter, F., Chowdhury, T. R., Mistry, S. K., Dey, D., Barua, M. K., Islam, M. A., Rahman, M. (2016). Water Quality Index for Measuring Drinking Water Quality in Rural Bangladesh: A Cross-Sectional Study. Journal of Health, Population and Nutrition, 35,4.

Aydin, H., Ustaoğlu, F., Tepe, Y., Soylu, E. N. (2021). Assessment of Water Quality of Streams in Northeast Turkey by Water Quality Index and Multiple Statistical Methods, Environmental Forensics, 22, 1-2, 270-287.

Çiçek, A., Köse, E., Tokatlı, C. (2019). Use OF factor analysis to Evaluate the Sediment Quality of a Significant Mining Area: Seydisuyu Stream Basin (Turkey). Polish Journal of Environmental Studies, 28(3), 2021-2025.

EC (European Communities), (2007). European Communities (drinking water) (no. 2), Regulations 2007, S.I. No. 278 of 2007.

Environmental Protection Agency (EPA) METHOD 200.7. (2001). Determination of Metals and Trace Elements in Water and Wastes by Inductively Coupled Plasma-Atomic Emission Spectrometry.

Köse, E., Çiçek, A., Uysal, K., Tokatlı, C., Emiroğlu, Ö., Arslan, N. (2015). Heavy Metal Accumulations in Water, Sediment and Some Cyprinidae Fish Species from Porsuk Stream (Turkey). Water Environment Research, 87(3), 195-204.

Köse, E., Çiçek, A., Uysal, K., Tokatlı, C., Emiroğlu, Ö., Arslan, N. (2016). Evaluation of Surface Water Quality in Porsuk Stream. University Journal of Science and Technology - C Life Sciences and Biotechnology, 4(2), 81-93.

Köse, E., Tokatlı, C., Çiçek, A. (2014). Monitoring Stream Water Quality: A Statistical Evaluation. Polish Journal of Environmental Studies, 23(5), 1637-1647.

Kükrer, S., Mutlu, E. (2019). Assessment of surface water quality using water quality index and multivariate statistical analyses in Saraydüzü Dam Lake, Turkey. Environmental Monitoring and Assessment, 191, 71.
Liu, C. W., Lin, K. H., Kuo, Y. M. (2003). Application of factor analysis in the assessment of groundwater quality in a Blackfoot disease area in Taiwan. Science of the Total Environment, 313, 77-89.

Manahan, S. E. (2011). Water Chemistry: Green Science and Technology of Nature's Most Renewable Resource. Taylor \& Francis Group, CRC Press.

Mukatea, S., Wagha, V., Panaskara, D., Jacobs, J. A., Sawantc, A. (2019). Development of New Integrated Water Quality Index (IWQI) Model to Evaluate the Drinking Suitability of Water. Ecological Indicators, 101, 348-354.

Tokatl1, C. (2019). Drinking Water Quality Assessment of Ergene River Basin (Turkey) by Water Quality Index: Essential and Toxic Elements. Sains Malaysiana, 48(10), 2071-2081.

Tokatli, C. (2021). Health Risk Assessment of Toxic Metals in Surface and Groundwater Resources of a Significant Agriculture and Industry Zone in Turkey. Environmental Earth Science, 80, 156.

Tokatl1, C., Uğurluoğlu, A., Köse, E., Çiçek, A., Arslan, N., Dayığlu, H., Emiroğlu, Ö. (2021). Ecological Risk Assessment of Toxic Metal Contamination in a Significant Mining Basin in Turkey. Environmental Earth Science, 80(17), 1-19.

Tokatlı, C., Köse, E., Arslan, N., Emiroğlu, Ö., Çiçek, A., Dayığlu, H. (2016). Water Quality of Emet Stream Basin. Uludağ University Journal of the Faculty of Engineering, 21(2), 9-24.

Tokatlı, C., Köse, E., Çiçek, A. (2014). Assessment of the Effects of Large Borate Deposits on Surface Water Quality by Multi Statistical Approaches: A Case Study of the Seydisuyu Stream (Turkey). Polish Journal of Environmental Studies, 23(5), 1741-1751.

Tokatlı, C., Ustaoğlu, F. (2020) Health Risk Assessment of Toxicants in Meriç River Delta Wetland, Thrace Region, Turkey. Environmental Earth Science, 79, 426.

Tokatl1, C., Varol, M. (2021). Impact of the Covid-19 Lockdown Period on Surface Water Quality in the Meriç -Ergene River Basin, Northwest Turkey. Environmental Research, 197, 111051.

TS 266, (2005). Sular-İnsani tüketim amaçlı sular. Türk Standartları Enstitüsü, ICS 13.060.20.

Turkish Regulations, (2004). Yüzeysel Su Kalitesi Yönetimi Yönetmeliği, 31 Aralık 2004, Resmi Gazete No: 25687, http://suyonetimiormansu.gov.tr.

Turkish Regulations, (2015). Yüzeysel Su Kalitesi Yönetimi Yönetmeliğinde Değişiklik Yapılmasına Dair Yönetmelik, 15 Nisan 2015, Resmi Gazete No: 29327, http://suyonetimiormansu.gov.tr. 
Tyagi, S., Sharma, B., Singh, P., Dobhal, R., (2013). Water Quality Assessment in Terms of Water Quality Index. American Journal of Water Resources, 1(3), 34-38.

Uslu, O., Türkman, A. (1987). Su Kirliliği ve Kontrolü. T.C. Başbakanlık Çevre Genel Müdürlüğü Yayınları, Eğitim Dizisi I, Ankara.

Ustaoğlu, F., Aydın, H. (2020). Health Risk Assessment of Dissolved Heavy Metals in Surface Water in a Subtropical Rivers Basin System of Giresun (north-eastern Turkey). Desalination and Water Treatment, 194, 222 -234 .

Ustaoğlu, F., Tepe, Y. (2019). Water Quality and Sediment Contamination Assessment of Pazarsuyu Stream, Turkey Using Multivariate Statistical Methods and Pollution Indicators. International Soil and Water Conservation Research, 7, 47-56.

Ustaoğlu, F., Tepe, Y., Taş, B. (2020). Assessment of Stream Quality and Health Risk in a Subtropical Turkey River System: A Combined Approach Using Statistical Analysis and Water Quality Index. Ecological Indicators, doi. org/10.1016/j.ecolind.2019.105815.

Varol, M. (2019). Arsenic and Trace Metals in a Large Reservoir: Seasonal and Spatial Variations, Source Identi- fication and Risk Assessment for Both Residential and Recreational Users. Chemosphere 228, 1-8.

Varol, M., Gökot, B., Bekleyen, A., Şen, B. (2012). Water Quality Assessment and Apportionment of Pollution Sources of Tigris River (Turkey) Using Multivariate Statistical Techniques-A Case Study. River research and applications, 28(9), 1428-1438.

Wang, J., Liu, G., Liu, H., Lamc, P. (2017). Multivariate Statistical Evaluation of Dissolved Trace Elements and a Water Quality Assessment in the Middle Reaches of Huaihe River, Anhui, China. Science of the Total Environment, 583, 421-431.

Wetzel, R. G. (2001). Limnology: Lake and River Ecosystems. Elsevier Academic Press.

WHO (World Health Organization), (2011). Guidelines for Drinking-water Quality. World Health Organization Library Cataloguing-in-Publication Data, NLM classification: WA 675.

Xiao, J., Wang, L., Deng, L., Jin, Z. (2019). Characteristics, Sources, Water Quality and Health Risk Assessment of Trace Elements in River Water and Well Water in the Chinese Loess Plateau. Science of the Total Environment, 650, 2004-2012.

\section{OCENA JAKOŚCI WODY W ZBIORNIKU ZAPOROWYM BOYALI (SINOP, TURCJA) ZA POMOCA WSKAŹNIKÓW EKOLOGICZNYCH I STATYSTYCZNYCH}

\section{ABSTRAKT}

\section{Cel pracy}

W niniejszej pracy przeanalizowano przestrzenno-czasowe wahania jakości wody w jeziorze Boyalı. Do analizy jakości wody wykorzystano wskaźnik jakości wody (WQI) oparty na normach Światowej Organizacji Zdrowia dotyczących wody pitnej i tureckie Rozporządzenia o Kontroli Jakości Wody (WQCR), a także niektóre metody wielostatystyczne.

\section{Materiak i metody}

W 2019 roku z 5 wybranych stacji na jeziorze co miesiąc pobierano próbki wody i mierzono łącznie 30 parametrów dotyczących jej jakości. W celu określenia różnic pomiędzy przestrzennymi i czasowymi poziomami jakości oraz klasyfikacji badanych lokalizacji wykorzystano Wskaźnik Jakości Wody (WQI), Analizę Czynnikową (FA) i Analizę skupień (CA).

\section{Wnioski}

Na podstawie zebranych danych stwierdzono, że zbiornik zaporowy Boyalı ma jakość wody klasy I i klasy II. Ogólnie rzecz biorąc, uzyskane wyniki WQI sugerowały, że chociaż doszło do znacznego pogorszenia jakości wody w miesiącach letnich, stwierdzono, że zbiornik otrzymał ocenę A - Doskonała jakość wody $(<50)$ we wszystkich analizowanych miesiącach i stacjach. Wartości WQI zarejestrowane w jeziorze wahały się od 16,4 do 27,8, a wykryte parametry limnologiczne w żadnym z badanych miesięcy i żadnej stacji nie przekraczały norm określonych dla wody pitnej ( $<50 \mathrm{w}$ WQI). W wyniku analizy czynnikowej 3 czynniki określiły 88,9\% wszystkich wariancji, a w wyniku analizy skupień określono 2 skupienia statystyczne.

Słowa kluczowe: zbiornik zaporowy Boyalı, wskaźnik jakości wody, analiza czynnikowa, analiza skupień 